\title{
PLURALISME HUKUM PROGRESIF: MEMBERI RUANG KEADILAN BAGI YANG LIYAN
}

\author{
Eko Mukminto ${ }^{1}$ dan Awaludin Marwan ${ }^{2}$ \\ ${ }^{1}$ Fakultas Hukum Universitas Negeri Semarang \\ ${ }^{2}$ Fakultas Hukum Universitas Bhayangkara \\ ekomukminto@gmail.com
}

\begin{abstract}
When ideological contestation in law is controlled by the logic of the majority. Then the consequences of the legal logic will be controlled by the logic of oppression. In this context, minorities whether based on religion, ethnicity, gender or sexuality are difficult to pursuit justice. Access to justice is possible as long as minority representation is also present in state law. This paper aims to examine the concept of legal pluralism in Progressive law. Thus, it will also provide alternative ideas for resolving the problem of discrimination of minority groups. Satjipto Rahardjo's Progressive law has a philosophical basis that sees that the discourse of law is never be final and legal pluralism will provide justice. In the progressive law reasoning, legal pluralism will be discussed with recognition and redistribution political theory, so that it will tear down constellation of hierarchical structures and provides justice for minorities or "the others". Therefore, state law is no longer the rule of majority.
\end{abstract}

Keywords: progressive law; pluralism; minority groups; recognition politics; redistribution politics

\begin{abstract}
Abstrak
Ketika kontestasi ideologi dalam hukum dikuasai oleh logika mayoritas. Maka konsekuensinya logika hukum akan dikuasai oleh logika penindasan. Dalam konteks ini, kaum minoritas entah itu berbasis agama, etnis, gender ataupun seksualitas sulit mendapat tempat di ruang keadilan. Sedangkan jalan menuju keadilan (access to justice) hanya dapat dimungkinkan sejauh representasi minoritas juga hadir dalam hukum negara. Tulisan ini bertujuan untuk mengkaji konsep pluralisme hukum yang mengeram dalam nalar hukum progresif. Dengan demikian secara paralel juga akan memberikan gagasan alternatif terhadap penyelesaian masalah diskriminasi pada kelompok minoritas. Pemikiran hukum progresif yang digagas oleh Satjipto Rahardjo mempunyai pijakan filosofis bahwa pemaknaan atas hukum merupakan diskursus yang tak pernah final dan cara berhukum pluralis memungkinkan artikulasi keadilan. Dalam alur nalar progresif tersebut, pluralisme hukum akan didiskursuskan secara paralel dengan teori politik rekognisi dan politik redistribusi sehingga dapat meretas konstelasi struktur hierarkis guna memberikan ruang keadilan bagi kelompok minoritas atau dalam literatur filsafat disebut dengan "yang liyan" (the other). Oleh karenanya hukum negara bukan lagi kehendak mayoritas.
\end{abstract}

Kata Kunci: hukum progresif; pluralism; kaum minoritas; politik rekognisi; politik redistribusi 


\section{A. Pendahuluan}

\section{Latar Belakang}

Dalam perkembangan ilmu hukum dominasi positivisme mengakibatkan ontologi hukum dimaknai secara rigid. Hukum menjadi suatu sistem yang tertutup, logis, netral dan tetap. Sebagai suatu sistem yang tertutup maka makna hukum mengalami reduksi sedemikian rupa sehingga dalam positivisme hukum akan selalu dilihat dalam karakter kesatuan dan penyatuan. Hukum juga hadir dalam bentuk unifikasi dan kodifikasi, dan juga bersifat nasional dan etatistik (Luhman, 2002). Dari sejarahnya, positivisme hukum lahir dari semangat untuk memodernisasi hukum dalam konteks kekuasaan negara. Hal tersebut memungkinkan negara-sebagai pengejawantahan kehendak umum - untuk menjadi suatu kekuasaan hukum yang dominan. Dengan kata lain makna hukum identik dengan perintah penguasa (Austin, 2000). Dalam konstruksi pemaknaan tersebut, negara menjadi otoritas yang memonopoli kehadiran hukum.

Di tradisi hukum kontinental, karakter hukum positif hadir dalam wujudnya yang menjunjung tinggi kepastian hukum dalam wujudnya yang tertulis, oleh karenanya seringkali yang paling berhak disebut dengan hukum hanyalah hukum negara saja, hukum yang lain semisal, hukum adat pun eksistensinya diakui sejauh hukum negara mengakuinya. Hal ini menunjukkan secara gamblang bahwa rekognisi atas eksistensi hukum pun harus melalui hukum negara. Konsekuensi dari logika hukum seperti ini merupakan hasil dari suatu pemikiran yang memandang hukum secara sentralistis. Pandangan ini menjadi suatu patologi saintifik tersendiri jika ditinjau secara empiris. Hal tersebut dikarenakan hukum hanya dipahami sebagai sesuatu yang eksklusif namun dapat berlaku umum pada setiap orang dan terlebih lagi diselenggarakan hanya oleh intitusi negara. Implikasinya, kontestasi nilai yang terjadi antar komunitas dalam masyarakat seolaholah dapat direngkuh dalam satu ruang pemaknaan. Dengan demikian asumsi- asumsi yang a priori atas hukum mengandaikan bahwa hukum itu netral dan bebas nilai sehingga dapat berlaku umum.

Kodrat hukum yang dimaknai sebagai sesuatu yang netral dan bebas nilai seolah menegasikan bahwa hukum bukanlah sebuah produk dari kontestasi sejarah dan politik. Kodrat hukum dalam kategori inilah yang disebut dengan keadaan ilusif, yang dalam pandangan Marxisme, ini yang disebut sebagai ideologi par excellencesuatu kesadaran palsu. Konsekuensinya, hukum seolah-olah diartikan lepas dari manifestasi kepentingan mayoritas sehingga kontradiksi dalam realitas sosial dapat ditopengi sedemikian rupa. Hukum dapat dipaksakan dalam suatu masyarakat dengan suatu argumentasi bahwa tak ada posisi yang oposisional antara mayoritas dan minoritas atau dalam bahasa yang retoris lebih lunak: negara berada diatas semua golongan. Nah, pertanyaannya jika negara memang berdiri diatas semua golongan maka seharusnya dalam realitas sosial, konflik nilai atau kontestasi kaidah yang terjadi dalam masyarakat takkan pernah ada (karena oposisi golongan diasumsikan tidak eksis dan hukum seharusnya merupakan representasi dari semua golongan) sehingga proposisi negara yang netral dan dianggap tidak mewakili kepentingan golongan tertentu menjadi proposisi yang invalid. Maka kemudian pertanyaannya diganti dengan pertanyaan yang adequate menjadi apakah dalam hukum yang seragamsentralistik-eksklusif tersebut, mampu untuk mengakomodir hak-hak dan kepentingan minoritas? Dalam tataran empiris, fakta berbicara lain. Kaum minoritas dari Jemaah Ahmadiyah, Penganut Syiah, komunitas LGBT hingga etnis Tionghoa misalnya, masih mendapatkan diskriminasi dan pelanggaran akan hak-hak sipilnya (Komnas HAM, 2016).

Dalam tataran normatif, perlindungan hukum dan hak asasi manusia memang telah diakui namun dalam tataran implementasinya hukum berada dalam ketidakpastian. Ketimpangan hukum juga terjadi pada eksistensi masyarakat adat. Di 
Indonesia, walaupun konstitusinya mengakui hukum adat sebagai suatu sumber hukum yakni Pasal 18 UUD 1945 Amandemen, namun dalam realitas sosial, hukum negara dengan peraturan perundangundangannya masih mendominasi realitas hukum. Implementasi hukum adat dalam kebijakan publik, belum mencerminkan absorbsi hukum adat sebagai suatu sumber hukum. Bahkan masih sering terjadi konflik antara institusi hukum dan masyarakat hukum adat dalam bidang pengelolaan tanah dan sumberdaya alam. Sekali lagi, hal ini seakan meneguhkan pendapat bahwa hukum negara adalah suatu sistem eksklusif yang tertutup. Melalui ketimpangan-ketimpangan tersebut pertanyaan tadi terjawab sudah, bahwa dalam logika hukum inilah nampak realitas hukum merupakan manifestasi kehendak mayoritas. Suatu logika hukum yang mengekslusi kaum minoritas dalam realitas sosial. Dari sinilah terlihat bahwa reduksi atas kompleksitas realitas menunjukkan bahwa hukum yang sentralistis tak senyata nyata dapat menyelesaikan permasalahan ketertiban dan keadilan. Maka dari itulah kajian ontologi hukum menjadi suatu hal yang tak dapat diingkari. Titik pijaknya adalah melihat fenomena realitas yang terdiri dari kemajemukan yang chaos. Keberagaman identitas subjek dan nilai serta kultur, yang dengan demikian kita harus menerjemahkan artikulasi hukum tidak secara singular, namun secara non-singular. Artikulasi hukum secara non-singular ini berdampak pada relasi hukum dan keadilan. Pemikiran dengan titik pijak yang kompleks ini membuat artikulasi keadilan pun menjadi debatable. Hal ini memuat suatu inisiasi bahwa kategori logika dan cara-cara berhukum secara konvensional menjadi tidak relevan lagi. Dengan demikian ontologi hukum dan keadilan harus didedah secara progresif sehingga ruang-ruang keadilan tidak hanya dalam lintasan satu pemaknaan. Kaum minoritas dan yang terpinggirkan diberi ruang dalam semesta keadilan.
Studi hukum progresif menginisiasi suatu kajian atas hukum dengan melihat bahwa kompleksitas dan realitas hukum dalam suatu keadaan yang dinamis. Kemajemukan nilai dan kaidah dikaji dalam eksistensinya yang progresif. Relasi kuasa dan eksistensi hukum negara tak lagi dilihat secara dominan namun dalam kemajemukan tatanan nilai dan kaidah yang ada setara dalam realitas sosial. Oleh karenanya urgensi penyelesaian atas problem diskriminasi atas kaum minoritas dapat ditempuh dengan jalan: yang pertama dengan mengkaji hakikat hukum negara dalam kontestasinya dengan kemajemukan nilai dalam realitas sosial. Kemudian yang kedua, menempatkan kajian atas pluralisme hukum progresif tersebut dalam relasinya dengan teori keadilan dan hak-hak sipil bagi kaum minoritas.

\section{Perumusan Masalah}

1. Bagaimana posisi teoritik pluralisme hukum progresif dan kritiknya atas dominasi logika hukum mayoritas?

2. Bagaimana memberi perlindungan hukum sebagai bentuk akses keadilan bagi yang liyan (kaum minoritas) dalam perspektif pemikiran pluralisme hukum progresif?

\section{B. Hasil dan Pembahasan}

1. Posisi Teoritik Pluralisme Hukum Progresif dan Pemaknaan atas Ontologi Hukum

\subsection{Pemikiran Hukum Progresif: Kritik} atas Dominasi Logika Hukum Mayoritas

Dalam kritiknya, hukum progresif melihat bahwa hukum negara terlalu dominan dan berperan sebagai pemain tunggal dalam setiap sektor kehidupan (Samekto, 2013). Realitas nilai-nilai dan norma dalam masyarakat mendapatkan legitimasinya dalam hukum negara. Namun satu hal yang selalu dipungkiri kenyataannya adalah bahwa jika dilihat dari proses pembentukannya, hukum merupakan hasil akhir dari suatu kesepakatan ataupun suatu konflik dalam masyarakat. Dengan 
menyitir Chambliss, masalah pembentukan hukum akan selalu hadir sebagai suatu adu kekuatan dimana negara merupakan senjata ditangan lapisan yang berkuasa (Rahardjo, 1980). Dengan demikian tujuan hukum yang berupa keadilan hanyalah merupakan resultan dari kontestasi nilai-nilai yang ada dalam masyarakat bukan sesuatu ihwal yang jatuh dari langit.

Menempatkan hukum negara sebagai kekuatan hukum yang dominan juga tak bisa dilepaskan dari perkembangan sejarah negara. Konsep ini lahir dari perkembangan doktrin Rule of law bahwa kekuasaan harus berdasar pada hukum, walaupun setiap negara dalam sejarahnya melewati suatu proses yang berbeda-beda namun doktrin ini dipakai oleh kebanyakan negara-negara untuk menetralisir aroma absolutisme kekuasaan dalam suatu kehidupan bernegara. Aspek politik dinetralkan sedemikian rupa. Dari sinilah kekuatan hukum negara (modern) menyeruak ke segala aspek kehidupan. Positivisasi hukum ini semula memang digunakan sebagai suatu konsekuensi atas keinginan meraih makna yang pasti dan mengatasi kebimbangan makna. Oleh karenanya, kepastian hukum, imparsialitas dan equality before the law menjadi frasa yang selalu didengungdengungkan oleh hukum positif. Hukum menjadi cara untuk memaknai realitas sehingga kondisi yang objektif selalu tercapai. Suatu peraturan hukum atau teks hukum akan mendefinisikan bagaimana perilaku dan relasi antar individu atau kelompok sosial satu dengan kelompok yang lainnya. Dalam proposisi positivistik ini teks hukum adalah prosedur kebenaran.

Hukum progresif melihat bahwa cara berhukum yang positivistik hanya akan mengerdilkan kebermaknaan dalam hukum. Melihat hukum negara sebagai satu-satunya pijakan dalam menerjemahkan realitas adalah tindakan mengabaikan dimensi substansial dalam hukum. Teks hukum menjadi entitas yang tertutup. Dengan kata lain hukum akan kerdil maknanya jika hanya bertumpu pada peraturan perundangundangan. Menurut Satjipto Rahardjo, mengeja suatu peraturan haruslah dieja dalam kontekstualisasinya dengan realitas, bagaimana relasinya dengan ruang dan waktunya. Teks haruslah dilihat dalam scope yang lebih luas. Melihat hukum secara positivistik juga mengandaikan pembacaan hukum yang netral dan bebas nilai. Namun suatu teks hukum, dalam perspektif hukum progresif, akan selalu merupakan jalinan semiotika dimana berkelindan konsep ideologi, sosial-kultural dan struktur kekuasaan. Dalam hal ini Satjipto Rahardjo memaparkan bahwa hukum tidak hanya bangunan peraturan saja melainkan suatu bangunan ide, kultur, dan cita-cita (Rahardjo, 2006). Hukum modern dan Rule of Law mempunyai konotasi yang netral tapi orang lupa bahwa dibalik struktur formal tersebut ada nilai dan gagasan tertentu.

Pengabaian struktur formal dibalik teks hukum adalah lahan subur tempat berseminya penindasan. Hukum yang netral adalah sebuah ideologi-suatu kesadaran palsu. Jalinan reproduksi makna yang mencoba menghegemoni dan meletakkan realitas dalam cerminan nilai-nilai dan ide serta kepentingan dibalik teks-teks peraturan. Disinilah letak kekuasaan hadir berselimut kehendak umum. Sehingga dapat dikatakan bahwa relasi hukum dan kekuasaan berada dalam diskursus yang sama.

\subsubsection{Yang Liyan dalam Kategori Hukum dan Kekuasaan}

Diskursus hukum hendaknya tidak mengabaikan diskursus tentang kekuasaan. Antara hukum dan kekuasaan terdapat kaitan yang berkelindan satu sama lain. Kelindan antar keduanya dapat kita lihat dalam terminologi hukum, yakni mengandaikan adanya anjuran, keharusan, dan adanya larangan. Bentuk-bentuk sublimasi hukum tersebut secara ilustratif memberikan gambaran akan keinginan, suatu cita yang ingin digapai, dan dalam kategori inilah kekuasaan bekerja. Analisis tentang kekuasaan berarti melihat secara faktual hukum bekerja, sebab hukum tanpa kekuasaan hanya tinggal ide belaka 
(Rahardjo, 1986). Relasi kekuasaan dan hukum mendapatkan wajahnya yang paling garang ketika bertransformasi menjadi hukum negara. Melalui kekuatan koersif institusi hukumnya, negara mampu mengintegrasikan dan menerjemahkan hak dan kewajiban dalam semua aspek kehidupan individu dan masyarakat.

Dalam kaitannya dengan hukum dan kekuasaan, Michel Foucault mengutarakan bahwa suatu kekuasaan juga mengkooptasi dimensi pengetahuan (Foucault: 1994). Dalam kategori ini; definisi pengetahuan merupakan suatu kekuasaan begitu juga sebaliknya. Hukum sebagai instrumen kekuasaan juga memainkan peranan sebagai penerjemah realitas. Dan semenjak hukum negara mendominasi semua lini kehidupan, maka pengetahuan akan realitas juga akan selalu bertolak dari hukum negara. Paparan Foucault tersebut, mengandaikan bahwa kedaulatan dan hak dalam hukum modern sedikit banyak ditafsirkan oleh negara. Konsep hukum seperti hak dan kewajiban juga hanya dimengerti sejauh hukum negara menafsirkannya. Hal ini memuat penyempitan makna sebab hak seseorang hanya diakui dan dilindungi sejauh negara memberikan landasan hukumnya. Dengan demikian kaum minoritas atau yang dalam teori kebudayaan sering disebut dengan Yang liyan (the others) merupakan kelompok yang tereksklusi dari hukum (Barzilai, 2010).

Hukum progresif mengkonstatasikan bahwa lingkup kekuasaan hukum modern dalam realitas sosial akan selalu terjadi persaingan makna. Kekuasaan hukum negara dalam kompleksitas sosial akan berbenturan dengan "hukum" yang lain. Hukum negara menjadi kekuatan yang hegemonial yang pada sejarah kemunculannya terjadi dari perubahan sebagai entitas yang semula alami menjadi bangunan nilai artifisial dengan karakter yang berbasis konstruksi rasional (Rahardjo, 2006). Kekuatan hegemonial ini akhirnya meminggirkan komunitas politik alami yang telah ada sebelumnya.
Hukum negara sebagai kekuatan hegemonial ini sejatinya hanya menopangi struktur yang lama. Karena pada dasarnya struktur yang lama masih bertahan, tidak tergusur dan tidak lenyap sama sekali. Realitas sosial yang dilihat dalam optik positivitik tak mampu melihat eksistensi struktur yang lama, yang tertopangi oleh kekuatan hukum modern. Hal tersebut dikarenakan, elemen dasar yang dijadikan pijakan dalam berhukum secara modern ini hanya berpijak kepada tujuan kepastian hukum.

Satjipto Rahardjo melihat bahwa kepastian hukum yang dibawa oleh hukum negara ini merupakan kepastian hukum dalam artian yang ilusif. Oleh karena mengabaikan kekacauan dan kompleksitas nilai-nilai dalam realita sosial. Kepastian hukum, dalam perspektif hukum negara hanya disejajarkan dengan kepastian peraturan perundang-undangan (Rahardjo, 2006). Jadi pada dasarnya kepastian hukum ini bukanlah suatu hal yang substansial dimana hukum sendiri berada dan bekerja pada sebuah matriks sosio-kultural yang sangat kompleks.

\subsection{Menempatkan kembali Hukum Negara dalam kontestasi Pluralitas Nilai-Nilai: Artikulasi Pluralisme Hukum Secara Progresif}

Kompleksitas dalam realita sosial merupakan hal yang tak dapat diabaikan. Kompleksitas ini menampilkan sebuah jaringan kebudayaan yang majemuk. Suatu istilah yang menurut Satjipto Rahardjo disebut sebagai Jagat ketertiban. Dalam kategori inilah kemajemukan tatanan dalam realita sosial merupakan sumber dari ketertiban hukum (Rahardjo, 2006). Yakni dengan menempatkan tatanan dan ketertiban sosial dengan tidak mengesampingkan aspek-aspek yang menujang kemajemukan atas realitas sosial, seperti tatanan ekonomi, politik, budaya dan sebagainya.

Dalam proposisi kemajemukan ini hukum negara akan dilihat sebagai salah satu komponen yang sebenarnya tidak dominan. Karena pada dasarnya bekerjanya 
hukum negara ini juga ditunjang dari efektifnya aspek dan komponen-komponen yang ada dalam kompleksitas jagat ketertiban. Sehingga dari proposisi ini, konsep hukum tidak hanya diartikulasikan sebagai sekumpulan peraturan perundangundangan yang dengan asumsi ilusifnya bekerja secara otomatis dan secara efektif memunculkan tatanan dan ketertiban.

Kondisi empiris masyarakat yang terdiri dari berbagai komponen, kaidah dan nilai dilihat sebagai suatu jaringan yang bekerja secara natural. Kemajemukan dalam masyarakat dilihat apa adanya. Maka pluralitas menjadi titik sentral dalam memandang hakikat realitas sosial. Oleh karena itu idea tentang hukum yang sentralistis akan mengabaikan hakikat hukum. Sentralisme hukum hanya akan menyempitkan dari makna hukum itu sendiri. Yang hal ini, pada kenyataannya dapat kita lihat bahwa hukum mencoba mengklasifikasi realitas berdasarkan kategori-kategori yang kaku. Dalam kategori ini hukum progresif dapat menjadi acuan dalam memunculkan makna hukum yang selaras dengan kompleksitas dan pluralitas realita sosial yang cair dan fluktuatif. Oleh karena hukum progresif basis filosofisnya berpijak dari anti kemapanan (anti establishment), maka hukum dikaji dalam konstruksi makna yang berada dalam antara. Dengan kata lain, kekuatan hukum progresif adalah kekuatan menolak dan mematahkan keadaan status quo (Rahardjo, 2006).

Dalam proposisi tersebut, dalam diri hukum progresif mengeram konsep berhukum yang melihat pluralisme nilai dalam ontologi hukum. Pemikiran hukum ini, melihat bahwa kondisi riil-materiil nilai dalam masyarakat adalah majemuk. Hukum dilihat sebagai entitas yang berpijak tak hanya mengakomodir nilai-nilai mayoritas saja namun juga berpijak pada nilai-nilai yang sifatnya partikular dalam kehidupan social. Oleh karenanya pluralisme hukum dapat dipahami sebagai sebuah kondisi dimana pengakuan akan hukum bukan saja dipahami sebagai penerimaan hukum secara formal, namun juga membuka ruang pemaknaan bagi entitas dan struktur-struktur "non hukum" yang berfungsi sebagai komponen-komponen pembentuk masyarakat.

Sally Engle Marry mengkonsepsikan pluralisme hukum (Marry, 1988) sebagai suatu keadaan dimana ada dua atau lebih sistem hukum dalam wilayah yang sama. Hal ini dikonsepsikan oleh Marry, dari definisi yang diajukan oleh Pospisil dan Griffith. Lebih lanjut, menurut Pospisil setiap subgroup dalam masyarakat mempunyai hukumnya sendiri-sendiri. Dengan terminologi subgroup disini, dimaksudkan dengan unit-unit masyarakat seperti keluarga, marga, suku dan komunitas sosial lainnya. Sedangkan dengan term sistem hukum diartikan secara umum mencangkup sistem peradilan dan hakim yang disokong oleh hukum negara dan sebagaimana juga tatanan non hukum secara formal. Tatanan non-hukum ini dapat berupa norma tertulis, peradilan adat dan bahkan ada yang mereplikasi struktur dan bentuk simbolis dari hukum negara.

Merunut pada apa yang didefinisikan oleh Griffith yang mengomentari definisi Pluralisme dari Vanderlinden (Griffith, 1986). Pluralisme Hukum adalah atribut dari group sosial yang spesifik. Suatu keadaan sosial dan karakteristiknya dapat diobservasi secara empirik, sehingga menurut Grifith, Pluralisme hukum bukanlah sebuah doktrin atau konsep ataupun teori maupun ideologi. Bahkan bukan pula atribut dari hukum atau sistem hukum dan juga tidak mempunyai hubungan dengan kondisi spasial territorial dan entitas sosial tertentu. Oleh karenanya dapat dimengerti, kondisi pluralisme hukum ini adalah fakta empiris dan berlaku umum pada setiap masyarakat.

Yang kedua, menurut Griffith, pluralisme hukum tidak membutuhkan kehadiran lebih dari satu keseluruhan sistem hukum. Mekanisme hukum yang jamak adalah cukup dalam satu aturan atau satuan intitusi hukum. Jadi definisi suatu sistem akan mencangkup keseluruhan atas kemajemukan realitas. Dapat dikonsepsikan bahwa pluralisme dalam pemikiran Griffith 
bersifat kodrati. Pluralisme ada dalam masyarakat dalam bentuknya yang azali, sehingga hukum yang majemuk bukanlah hukum yang berada dalam konstruksi idea atau pemikiran.

Pluralisme hukum dalam kajian Grifith, hukum dalam bentuk plural akan selalu ada dalam masyarakat yang hadir dalam bentuk apapun. Hal itu dikarenakan adanya dinamika dan kompleksitas yang ada dalam masyarakat itu sendiri. Dari proposisi Griffith dapat dikonstatasikan bahwa hukum semenjak diartikan sebagai sebuah instrumen dalam masyarakat, dan dalam masyarakat yang majemuk, eksistensi kemajemukan hukum akan selalu ada. Dengan kata lain Masyarakat yang majemuk akan memunculkan kehadiran nilai yang majemuk pula.

Pluralisme hukum sendiri juga dapat diartikan sebagai suatu keadaan empiris dalam masyarakat, yang mencangkup tidak hanya sistem hukum yang berdampingan namun juga bersifat pandangan pluralisme hukum yang formal. Pluralisme tersebut dapat disebabkan oleh adanya dualisme sistem hukum yang terjadi akibat kolonialisme dari bangsa-bangsa Eropa yang memaksakan hukumnya berlaku didaerah jajahan mereka, ini yang disebut sebagai pencangkokan hukum (Faturokhman, 2009).

Pencangkokan hukum ini banyak terjadi di daerah-daerah bekas jajahan. Disini Indonesia dapat dijadikan contoh, Hukum kolonial dimasa pemerintahan Hindia Belanda dipaksakan ke masyarakat pribumi yang mengakibatkan kompleksitas hukum pada tataran sosial. Oleh karenanya sistem hukum di Hindia Belanda menjadi plural. Ada beberapa sistem hukum yang berdampingan, yakni Hukum kolonial, Hukum Adat dan Hukum Islam. Pencangkokan hukum ini di beberapa negara, terutama bekas jajahan Spanyol, seperti di Amerika latin tidak hanya menghegemoni dalam hal hukum formal namun juga substansi agama yang dipengaruhi oleh gereja Katholik juga dicangkokan ke masyarakat pribumi dengan mengkonversi keyakinan lokal (Tamanaha,
2007) sehingga gereja Katholik pun menjadi struktur yang inheren dalam perkembangan kehidupan masyarakat di Amerika latin.

Konsep pluralisme hukum dan pencangkokan hukum ini membuat studi akan pluralisme hukum sendiri tak dapat dilepaskan dari studi atas sejarah kolonialisme dan pasca-kolonial. Dalam aras ini, studi pluralisme seringkali mengkaji tentang pertalian dan persimpangan antara hukum kolonial dan hukum Pribumi (hukum adat). Masalah yang timbul pasca dekolonisasi adalah hukum kolonial menjadi dominan daripada hukum adat-pribumi oleh karena hukum kolonial ini kemudian diambil alih oleh negara pasca-koloni. Hal inilah yang kemudian menjadikan problema hukum yang terjadi pada masyarakat pascakolonial, yakni dalam hal dominasi sistem hukum. Sistem hukum dalam masyarakat pasca koloni mengambil alih sistem hukum kolonial sebagai sistem hukum utamanya. Tatanan dan norma hukum adat biasanya hanya diberlakukan pada masalah hukum yang menyangkut hal-hal privat, seperti hukum keluarga, perkawinan, hukum agama dan lain sebagainya (Tamanaha, 2007). Letak permasalahannya adalah pencangkokan yang telah ada sejak jaman kolonial ini ketika diaplikasikan ke masyarakat pasca-kolonial mengabaikan bekerjanya hukum dalam tataran empirik, karena penerimaan norma dan kaidah dalam masyarakat tidak membuat hukum bekerja secara efesien maka terjadi diskrepansi antara hukum negara dan hukum yang hidup dalam masyarakat. Hal inilah yang menimbulkan logika hukum dan logika masyarakat tidak berjalan pada aras yang sama.

Logika hukum dan logika masyarakat yang tak terjembatani ini berimplikasi tidak hanya pada efektif atau tidaknya hukum bekerja dalam masyarakat, namun juga pada artikulasi keadilan. Penerjemahan keadilan menurut hukum (negara) dan penerjemahan keadilan masyarakat berada pada titik ordinat yang berbeda, sehingga seringkali masyarakat melihat bahwa tujuan hukum yakni keadilan tidak dapat digapai melalui 
hukum (negara). Pada kasus-kasus tertentu, ketidakpuasan masyarakat terhadap bekerjanya hukum membuat masyarakat menempuh jalur-jalur vigilanteisme. Benturan antara logika hukum dan logika (hukum) masyarakat juga membuat masyarakat dan negara berhadap-hadapan. Hal inilah yang menjadikan sebab musabab sering terjadinya konflik antara masyarakat hukum adat dengan negara.

Perkembangan kajian pluralisme hukum kemudian beralih dari kajian hukum kolonial dan pasca kolonial kepada kajian kontemporer terhadap relasi kuasa dan dominasi antara kelompok dalam masyarakat (Marry, 1988). Relasi antara kelompok dominan dan kelompok subordinat, antara mayoritas dan minoritas seperti relasi agama, etnik atau minoritas kultural, kelompok imigran dan lain sebagainya. Pada perkembangan ini kajian perhatiannya ditujukan pada pertanyaan atas efek hukum terhadap masyarakat atau bahkan efek masyarakat pada hukum yang mengacu pada konseptualisasi kompleksitas dan relasi interaktif antar tatanan hukum (tatanan yang formal atau non-formal).

Kajian Pluralisme yang terakhir ini dapat dikatakan sebagai sebuah perkembangan dari pluralisme klasik ke pluralisme kontemporer. Menurut Marry, kajian pluralisme kontemporer mempunyai kontribusi teoritik terhadap masyarakat pasca-kolonial. Yakni, yang pertama, bahwa analisis atas interaksi antara tatanan normatif yang berbeda dalam hal landasan konsep terhadap struktur. Yang kedua, fokus pada elaborasi hukum kebiasaan yang secara historis terberi. Dan yang ketiga, pengambaran atas dialektika tatanan normatif. Kajian kontemporer lebih menekankan kontestasi nilai dan tatanan norma dan relasinya didalam masyarakat mikro.

Pluralisme hukum, dari apa yang telah dikemukakan tersebut, menunjukkan bahwa tatanan norma yang hidup dalam masyarakat merupakan salah satu bentuk hukum yang tak dapat dipungkiri keberadaannya. Definisi hukum tak lagi ditempati oleh hukum negara saja melainkan ada entitas hukum yang lain hadir dalam masyarakat. Hal ini mempunyai konsekuensi bahwa suatu standar nilai tidak dimaknai tidak dari poros hukum negara saja. Namun suatu nilai dalam norma akan diterjemahkan dari kompleksitas dan relasi interaktif dalam suatu komponen masyarakat. Sejalan dengan proyek hukum progresif, kajian pluralisme hukum memberi topangan epistemik bagi hukum progresif. Sehingga dalam kuadran ini, tujuan dari hukum progresif sebagai kritik atas dominannya hukum negara tidak hanya membedah relasi hukum negara dan hukum nonformal namun juga konstruksi akses keadilan bagi kelompok minoritas dalam konstelasi relasi kuasa-hukum.

Lebih lanjut konsekuensi pemikiran pluralisme hukum dan relasinya dengan pluralisme keadilan adalah bagaimana cara menempatkan keadilan bagi kelompok minoritas dalam konstruksi jaminan perlindungan hukum dan kesetaraan sosial. Pada aras kajian pluralisme inilah, hukum progresif mendapatkan tantangan yang paling riil, oleh karenanya hal yang harus diselesaikan adalah permasalahan pada level politik hukum sehingga dari kajian hukum progresif akan menyoroti permasalahan hierarki dan struktur serta dominasi antar kelompok masyarakat juga relasi antara negara dengan kelompok minoritas.

\section{Pluralisme Hukum Progresif dan Ruang Keadilan bagi Yang Liyan: Menimbang Politik Rekognisi atau Redistribusi?}

Dari pemaparan dimuka, artikulasi pluralisme hukum dengan nafas yang progresif telah membuka inisisasi perdebatan keadilan pada level filosofis. Ekuasi keadilan diformulasikan tidak dalam konjungturnya yang utuh-terberi. Tak lagilagi artikulasi keadilan diserahkan secara sembrono ditangan para reduksionis hukum yang melihat dominasi hukum negara sebagai satu-satunya penyedia akses keadilan. Ruang-ruang keadilan akan didiskursuskan sedemikian rupa sehingga membuka tempat bagi yang liyan-bagi yang 
terpinggirkan untuk masuk dalam pemaknaan keadilan. Dalam konstruksi cita hukum progresif yang dimaksud dengan keadilan adalah keadilan substantive. Dengan demikian hukum progresif akan membuka diri dalam wacana perdebatan filosofis.

Apa yang dimaksud dengan substantif? Seperti pada apa yang telah dikemukakan sebelumnya bahwa penerjemahan keadilan adalah kerja filosofis oleh karenanya istilah substantif ini akan merujuk pada konstalasi filsafat. Substansi sendiri merupakan kajian metafisika yang merujuk pada entitas atau kehadiran objek. Apabila basis filosofis hukum progresif adalah kemenjadian (becoming), maka dalam kategori ini substansi keadilan akan dimaknai dalam perkembangan makna sesuai konteks ruang dan waktu.

Keadilan sebagai tujuan dari hukum pada akhirnya akan diartikulasikan dalam perspektif yang plural-keadilan pluralistik. Apa yang disebut dengan keadilan pluralistik ini adalah menempatkan artikulasi kesetaraan dalam statusnya yang jamak. Setiap komponen masyarakat akan dilihat sebagai subjek yang setara (equal) dan dengan tidak mengabaikan kelompok minoritas dalam lingkup sosial-politik yang berarti melihat kompleksitas dalam masyarakat tidak dalam perspektif keseragaman. Keadilan akan dilihat dalam rangkaian multiplisitas yang majemuk. Karena itu masyarakat adat, komunitas minor (sex, ras, gender) dan komunitas agama akan dilibatkan dalam suatu diskursus namun masih berpijak pada partikularitas mereka. Alasan-alasan partikularitas mereka tidak boleh diabaikan ataupu dipinggirkan dalam proses menentukan tujuan-tujuan kolektif.

Dalam kaitannya dengan proses kolektif ini, cita-cita partikular ini akan menghadapi tantangan dimana legitimasi etis-politis dibutuhkan untuk menopang kebenaran. Kita dapat menilik perspektif Habermas yang melihat bahwa masyakat yang kompleks ini mengisyaratkan sebuah legitimasi kongkret bagi tujuan-tujuan particular (Habermas, 2009). Suatu dasar yang dapat merangkul berbagai kepentingan dalam multiplisitas sosial karena apa yang dianggap baik dalam satu komponen masyarakat belum tentu baik dalam perspektif yang lain sehingga legitimasinya harus berpijak pada Hak Asasi Manusia.

Dimuka juga telah disinggung mengenai keadilan yang pluralistik, dan dalam kaitannya dengan keadilan yang dapat merangkul kelompok minoritas, kita dapat mengacu pada perdebatan teoritik dewasa ini, yakni tentang teori keadilan yang bertumpu pada dua konsep filsafat politik; yang pertama adalah politik rekognisi dan yang kedua, politik redistribusi (Fraser \& Honneth, 2004). Yang pertama, yakni; politik rekognisi merupakan suatu perjuangan mendapatkan pengakuan atas eksistensi minoritas oleh mayoritas, yang muncul sebagai respon atas diskriminasi sosial-gender, agama sex, ras, dsb. Sedangkan yang kedua, redistribusi merupakan sebuah teori keadilan yang dioperasikan dari politik yang bertolak dari asumsi yang berfokus pada ketidakadilan disebabkan oleh ketimpangan sosial ekonomi.

Perdebatan antara rekognisi dan redistribusi berpijak pada premis bahwa politik rekognisi merupakan suatu suatu hal yang fundamental sedangkan redistribusi hanyalah derivatifnya. Pendapat ini dipegang oleh Charles Taylor dan Axel Honneth. Premis yang kedua, oleh Nancy Fraser yang melihat bahwa analisis atas keadilan haruslah berada pada konsepsi "dwi-dimensional", maksudnya keadilanlah yang meliputi klaim antara redistribusi dan rekognisi tanpa mereduksi keduanya. Pada dasarnya poros perdebatan antar keduanya, bertolak pada konsepsi kontemporer atas relasi hierarkis dalam kebudayaan dan ekonomi. Persoalan dalam tatanan ekonomi atau tatanan kebudayaan yang mana lebih berpengaruh dalam artikulasi keadilan. Mana yang lebih krusial antara diskriminasi sosial atau ketimpangan ekonomi. Dalam diskursus keadilan kontemporer tersebut 
menampak bahwa ada dua kenyataan keadilan.

Axel Honneth memaparkan bahwa politik rekognisi ini hadir sebagai pengejawantahan filsafat Hegelian tentang intersubjektivitas dalam tataran perjuangan politik. Rekognisi atau pengakuan hadir sebagai suatu konsekuensi atas adanya hierarki dan diskriminasi sosial kultural. Politik rekognisi adalah perjuangan atas kesetaraan pada level kultural dalam masyarakat yang hierarkis. Yakni masyarakat yang melihat adanya hierarki nilai, dan norma-kaidah. Sebagai misal, ras kulit hitam lebih inferior dibanding kulit putih atau pengaruh budaya patriarki yang melihat laki-laki lebih superior daripada perempuan. Perjuangan rekognisi menjadi penting dikarenakan hierarki dan diskriminasi dalam sejarahnya ini telah melembaga sedemikian rupa dalam bentuk simbol-simbol normatif, hukum dan kultur negara. Oleh karena itu hanya melalui rekognisi atas identitas-identitas yang partikular perjuangan akan kesetaraan dapat diraih. Hal ini dapat disebut kulturisasi konflik sosial, disini identitas kultural dapat dijadikan gerakan resistensi moral-politik.

Politik redistribusi mengakar pada teori politik sosial-demokrat yang melihat semua ketimpangan sosial merupakan akibat ketidaksetaraan dalam hal ekonomi. Oleh karenanya perjuangan keadilan akan bertumpu pada kajian relasi dalam mode produksi dengan kata lain seluruh masalah ketidakadilan akan bersumber pada ketidaksetaraan dalam hal distribusi sumber daya. Dengan kata lain ketimpangan kelas sosial.

Menurut Nancy Fraser, persoalan dualitas keadilan tersebut mengabaikan kapilerisasi antar keduanya (Fraser \& Honneth, 2004). Ekonomi, kata Fraser, bukan zona bebas kultur, sebab kultur merupakan instrumen sekaligus alat penanda dalam ekonomi. Dalam relasi produksi kapitalisme misalnya buruh laki-laki dan buruh perempuan mempunyai akar historis tersendiri dalam sejarah kapitalisme. Dalam hal ini gender memainkan penandaan kultural yang mana tunduk dalam penandaan dalam tujuan-tujuan kapital, begitu juga sebaliknya penandaan ekonomi juga dipengaruhi oleh aspek historik dari kultur. Oleh karenanya, melihat dualitas perjuangan akan keadilan dalam dua logika yang berjalan sendiri-sendiri; rekognisi lepas dari redistribusi dan sebaliknya akan mebuat perjuangan selalu gagal. Mereduksi term ketidakadilan dalam kultur dengan logika perjuangan ekonomi dan sebaliknya akan menghasilkan kesalahpahaman akan persoalan keadilan.

Pluralisme hukum secara progresif melihat bahwa implementasi akan keadilan bagi kaum minoritas tidak harus termanifestasikan dalam hukum negara, Dalam kategori politik rekognisi; pengakuan akan eksistensi minoritas agama, atapun minoritas etnis/ras dan gender misalnya, tidak dalam aras untuk melegitimasi mereka secara hukum positif saja namun yang terpenting adalah meredefinisi struktur hirarkis yang ada dalam masyarakat. Bagaimana penerimaan mayoritas akan hal tersebut. Hal ini dimaksudkan agar makna keadilan tidak dimaknai dalam artikulasinya yang sempit. Dikarenakan dalam kompleksitas masyarakat majemuk, definisi marjinalisasi dan hierarki sosial kultural tidak hanya menubuh dalam satu kategori identitas; misal seorang keturunan Tionghoa bisa juga menyandang disabilitas, miskin dan tidak beragama monotheis atau orang jawa yang penganut Syiah atau Ahmadiyah sehingga jika perjuangan akan pengakuan hanya ada pada koordinat hukum positif saja akan parsial dan tidak akan efektif.

Perjuangan atas keadilan dalam pluralisme hukum progresif dimengerti sebagai suatu gerak perjuangan untuk merubah struktur hierarkis dalam masyarakat yang semula berada dalam perspektif moralitas yang singular kearah yang plural. Jika perjuangan ini berada dalam koordinat identitas/status sosial maka merubah atau meredefinisi kondisi yang memungkinkan terjadinya hierarki dalam masyarakat itulah yang terpenting untuk dirubah. Merubah perspektif tentang adanya 
suatu kebudayaan, agama, dan gender atau orientasi seksual yang lebih unggul atau ada etnis atau ras yang lebih sempurna dari yang lainnya juga merupakan syarat objektif untuk menghadirkan pluralisme makna keadilan. Perjuangan politik keadilan ini dapat berbentuk diskursus-diskursus publik, gerakan sosial-politik dan strategi-strategi pendidikan politik kultural emansipatif lainnya. Oleh sebab itu, komponenkomponen gerakan hukum progresif harus membuat poros diskursus moralitas yang plural untuk menjadi tema yang krusial guna menentukan bekerjanya logika pluralisme hukum yang dapat menghantarkan keadilan bagi kaum minoritas (keadilan bagi yang liyan).

\section{Simpulan}

Dari pemaparan diatas dapat dirumuskan kembali dalam beberapa hal, yang pertama mengenai status ontologis hukum, yakni: hukum yang hanya bersandar pada hukum negara yang positivistik mempunyai suatu patologi teoritik jika dihadapkan pada hakikat hukum secara empirik. Dalam kenyataan sosial, hukum negara senyata-nyata problematik karena pada dasarnya ketertiban dalam masyarakat sejatinya bekerja secara natural. Jagat ketertiban ini tidaklah serta merta hasil dari ketertiban dari tatanan yang disebut hukum negara. Yang kedua, kompleksitas dalam masyarakat memungkinkan pemaknaan hukum secara plural. Hal ini mempunyai konsekuensi bahwa artikulasi keadilan pun akan dimaknai tidak dari hukum negara saja. Namun hakikat keadilan akan diterjemahkan dari kompleksitas dan relasi interaktif antar tatanan hukum (formal-nonformal). Yang ketiga, dalam proyeksi hukum progresif, kajian pluralisme hukum memberi topangan epistemik bagi hukum progresif oleh karena itu tujuan dari hukum progresif sebagai kritik atas dominannya hukum negara tidak hanya membedah relasi hukum negara dan hukum non-formal namun juga merekonstruksi akses keadilan bagi kelompok minoritas. Perjuangan pluralisme hukum progresif dalam mewujudkan keadilan substansial-plural tidak terbatas pada rekognisi negara atas hak-hak kaum minoritas namun juga yang terpenting bagaimana merubah prakondisi yang menyebabkan struktur hierarki dan diskriminasi yang terjadi didalam masyarakat.

\section{DAFTAR PUSTAKA}

Austin, John. (2000). Province of Jurisprudence Determined. Cambridge University Press. New York.

Budi Hardiman, Fransiskus. (2009). Demokrasi Deliberatif: Menimbang 'Negara Hukum' dan 'Ruang Publik' Dalam Teori Diskursus Jurgen Habermas. Kanisius. Jogjakarta.

Barzilai, Gad. (2010). Communities and Law: Politics and Cultures of Legal Identities. Michigan University Press. Michigan.

Fraser, Nancy dan Honneth, Axel. (2004). Redistribution and Recognition: A Philosophical-Political Exchange. Verso. New York.

Hunt, Alan dan Whickam, Gary. (1994). Foucalt and Law: Toward Sociology of Law as Governance. Pluto Press. London.

Kaum Tjipian. (2009). Pemikiran Hukum Baru; Dari Kera ke Manusia, Dari Positivistik ke Progresif. Genta Press. Jogjakarta.

Marwan, Awaludin. (2013). Satjipto Rahardjo: Sebuah Biografi Intelektual dan Pertarungan Tafsir dalam Filsafat Hukum Progresif. Thafa Media, Jogjakarta.

Rahardjo, Satjipto. (1986). Ilmu Hukum. Almuni. Bandung. (2006). Sisi-Sisi Lain dari Hukum di Indonesia. Kompas. Jakarta. (2006). Hukum Dalam Jagat Ketertiban: Bacaan Mahasiswa Program Doktor Ilmu Hukum Universitas Diponegoro. UKI Press. Jakarta.

Membedah Hukum Progresif. Kompas. Jakarta. 2008 
Tamanaha, Brian. (2007). Understanding Legal Pluralisme: From Present to Past. From Local to Global. Sidney Law Review; Vol. 30.

Wignjosoebroto, Soetandyo. (2002). Hukum, Paradigma, Metode dan Pilihan Masalah: 70 Tahun Prof. Soetandyo. Elsam dan Huma. Jakarta.

\section{Jurnal}

Marry, 1988. Sally Engle. Legal Pluralism. Law and Society Review; Vol 22.

Griffith, 1986. John. What Is Legal Pluralism, Journal of Legal Pluralism.

\section{Website}

Komisi Nasional Hak Asasi Manusia. Laporan Komisi Hak Asasi Manusia RI Tahun 2014 Retrieved from; http://www.komnasham.go.id/pengawas an/laporan-akhir-tahun-kebebasanberagamaberkeyakinan-komnas-ham-ri$\underline{2014}$ 